ISSN 1392-3196

Zemdirbyste-Agriculture, vol. 100, No. 1 (2013), p. 57-62

UDK 633.11:631.8:631.55 / DOI 10.13080/z-a.2013.100.008

\title{
Changes in technological properties of common wheat (Triticum aestivum L.) grain as influenced by amino acid fertilizers
}

\author{
Rūta DROMANTIENĖ, Irena PRANCKIETIENĖ, Gvidas ŠIDLAUSKAS, \\ Viktoras PRANCKIETIS \\ Aleksandras Stulginskis University \\ Studentų 11, Akademija, Kaunas distr., Lithuania \\ E-mail: ruta.dromantiene@asu.lt; irena.pranckietiene@asu.lt
}

\begin{abstract}
Experiments with the winter wheat (Triticum aestivum L.) variety 'Širvinta 1' were conducted at the Experimental Station of the Lithuanian University of Agriculture (currently - Aleksandras Stulginskis University) during the period 2006-2009 in limnoglacional silty loam on morainne clay loam Cal(ca)ri-Endohypogleyic Luvisol (LVg$n-w-c c)$. The crops were grown on the background of $\mathrm{N}_{150} \mathrm{P}_{90} \mathrm{~K}_{90}$ mineral fertilization and were additionally foliarfertilized with amide nitrogen fertilizer, containing different concentrations (0.5-3.0\%) of amino acids, at heading stage BBCH 51-56. Experimental evidence showed that winter wheat grain yield increased by $0.13-0.37 \mathrm{Mg} \mathrm{ha}^{-1}$ under the effect of amino acids. The amino acid fertilizers improved technological properties of grain. Having fertilized with $0.5-2.0 \%$ amino acid solutions, the protein content increased by $0.62-0.81$ percentage points; having fertilized with $0.5-3.0 \%$ solutions the sedimentation values increased by $3-4 \mathrm{ml}$; and having fertilized with $0.5-1.0 \%$ amino acid solutions the wet gluten content increased by 1.1-1.7 percentage points. An increase in the falling number by $22 \mathrm{~s}$ occurred having fertilized with $1.0 \%$ amino acid solution. The study showed a statistically significant dependence of winter wheat grain yield $\left(\eta=0.93^{*}\right)$, protein content $\left(\eta=0.70^{*}\right)$ and sedimentation values $\left(\eta=0.98^{*}\right)$ on the concentration of amino acids in liquid amide nitrogen fertilizers.
\end{abstract}

Key words: amino acids, falling number, grain yield, heading stage, protein content, sedimentation, Triticum aestivum, wet gluten.

\section{Introduction}

The winter wheat is the most common cereal crop cultivated in Lithuania. A high grain yield and quality are important for food and feed production. Winter wheat yield and quality are determined by a host of environmental factors; however, the high grain yield and quality can be achieved only by maximally approximating crop growth, development, wintering, nutrition, yield structural elements' formation and other conditions, varying in relation to natural-climatic factors, soil peculiarities, agronomic practices applied or crop cultivation technologies to optimal ones. The quality of winter wheat yield depends on physiological-biochemical processes, which occur in plants during ontogenesis. They are partly determined by inherent indicators and a number of environmental factors during vegetation (Johansson et al., 2003; Švec et al., 2006; Лёвкин, 2007).

During late stages of plant development, leaf fertilizers activate not only the photosynthesis, but also stimulate root system regeneration, and extend productive vegetation. As a result, to achieve high grain protein nutritional quality, the plants must be supplied with nitrogen, not only at early stage, but, also, at late stages of development (Sylvester-Bradley et al., 1997; Daniel, Triboi, 2000; Woolfok et al., 2002;

Janušauskaitė, Šidlauskas, 2004). Crop productivity can be increased by improving and regulating the growth conditions, in addition, by promoting the photosynthetic activity (Dreccer et al., 2000; Sharma-Natu, Ghildiyal, 2005). The amino acids (biostimulants) may reduce the application of fertilizers and improve the quality of some plants. Biostimulants work by increasing plant mineral uptake and improving the nutrients use efficiency (Vernieri et al., 2005). According to Nikiforova et al. (2006), amino acids promote development of the root system and activate growth of the above-ground plant part. The author claims that the intensity of mineral nutrition elements' intake through the roots depends on the amount of aspartic and glutamic acids in plants. Experiments showed that the amino acids, which were used for plant fertilization, promoted the processes of a plant respiration, photosynthesis, and water cycle. In addition, the amino acids increased the concentration of ascorbic acid, accelerated protein synthesis, moreover, promoted plant growth and yield formation (Alaru et al., 2003; Meijer, 2003).

A positive impact of these substances can be conditioned, also, because the amino acids in the plants make chelate combination with the mineral elements, 
especially with microelements which are involved in carrying electrons between active proteins. Research showed that yield maturation time shortens, in addition, chlorophyll function activates, the amount of a sugar and essential amino acids - lysine, threonine, tryptophan increases because of amino acids effect (Azevedo et al., 2006). When winter wheat is foliar-fertilized with the amino acid fertilizers, the sorption of these substances does not depend on the chlorophyll function, so the plants can use them directly, thus saving energy. The current study was aimed to determine the effect of different concentrations of amino acids on the winter wheat crop productivity and quality. Amino acids were applied together with liquid amide nitrogen, used for additional winter wheat foliar-fertilization during heading stage BBCH 51-56 stage.

\section{Materials and methods}

A field experiment was set up at Lithuanian University of Agriculture's Experimental Station during the period 2006-2009. A total plot size was $45 \mathrm{~m}^{2}$ $(3 \times 15)$, and harvested plot size $26.4 \mathrm{~m}^{2}(2.2 \times 12)$. The plots were arranged in a randomized block design with four replications. The Lithuanian winter wheat (Triticum aestivum L.) variety 'Širvinta 1' was grown. The crop was sown at $200 \mathrm{~kg} \mathrm{ha}^{-1}$ (4.5 million seeds per ha' $\left.{ }^{-1}\right)$. The experiments were conducted on a limnoglacional silty loam on morainne clay loam Cal(ca)ri-Endohypogleic Luvisol $(L V g-n-w-c c)$ with a $\mathrm{pH}_{\mathrm{KCl}}$ of 6.8-7.5, phosphorus $\left(\mathrm{P}_{2} \mathrm{O}_{5}\right)$ content of $255-355 \mathrm{mg} \mathrm{kg}^{-1}$, potassium $\left(\mathrm{K}_{2} \mathrm{O}\right)$ content of $153-185 \mathrm{mg} \mathrm{kg}^{-1}$, mineral nitrogen $\left(\mathrm{N}_{\min }\right)^{2}$ content of $24.71-32.21 \mathrm{~kg} \mathrm{ha}^{-1}$ and a total nitrogen $(\mathrm{N})$ content of $0.12-0.14 \%$. Soil humus content was $2.22-2.41 \%$.

The winter wheat background fertilization: granulated superphosphate $\left(\mathrm{P}_{90}\right)$ and potassium chloride $\left(\mathrm{K}_{90}\right)$ were applied in the autumn, before sowing; urea $\left(\mathrm{N}_{90}\right)$ was applied in the spring after the winter wheat resumption of vegetation (BBCH 22-24). Additionally, the winter wheat was foliar-fertilized with liquid amide nitrogen fertilizer $\mathrm{N}_{30}$ at the booting stage (BBCH 32 $35), \mathrm{N}_{20}$ at the heading stage (BBCH 51-56) and $\mathrm{N}_{10}$ at the milk maturity stage (BBCH 71-75). In the plots of treatments $2-7$, the liquid amide nitrogen fertilizers were applied in combination with the amino acids at $\mathrm{BBCH}$ 51-56 stage. The following concentrations of amino acids were used $0.5,1,1.5,2,2.5$ and $3 \%$. The composition of liquid amide nitrogen fertilizer: $\mathrm{N}-\mathrm{NH}_{2} 18.5 \%$; product of amino acids composed of amino acids - peptides $50 \%$, organic nitrogen $8 \%$, water $<40 \%$ (further in the study referred to as amino acids). The total volume of solution is $400 \mathrm{l} \mathrm{ha}^{-1}$. The qualitative composition of amino acids present in the fertilizer $\left(\mathrm{g} \mathrm{kg}^{-1}\right)$ : aspartate (40.7), threonine (21.51), serine (60.91), glutame (37.78), glycine (35.49), alanine (24.60), valine (28.68), methionine (4.10), isoleucine (18.24), leucine (40.56), tyrosine (1.83), phenylalanine (25.38), histidine (1.63), lysine (2.77) and arginine (33.27).

Experimental and analytical methods. The soil was analyzed for: $\mathrm{pH}_{\mathrm{KCl}}$ was measured in $1 \mathrm{~N} \mathrm{KCl}$ extraction using a potentiometric method, humus content by Tyurin method, available phosphorus $\left(\mathrm{P}_{2} \mathrm{O}_{5}\right)$ and available potassium $\left(\mathrm{K}_{2} \mathrm{O}\right)$ by Egner-Riehm-Domingo (A-L) method, mineral nitrogen $\left(\mathrm{N}_{\min }\right)$ by $1 \mathrm{~N} \mathrm{KCl}$ extraction, the total nitrogen was measured by Kjeldahl method. The protein content (\%) was calculated by multiplying nitrogen content determined by Kjeldahl method by a coefficient 5.7 (ISO 712), flour sedimentation (ml) by Zeleny method (ICC 118 and ICC 116/1), falling number (s) by Hagberg and Perten method (ISO 3093), wet gluten content $(\%)$ having washed dough according to Perten, having calculated the data for the grain of $14 \%$ moisture (ICC 155).

Statistical analysis. The data of plant productivity and chemical composition indicators were processed by a two-factor analysis of variance (ANOVA) using the software package SELEKCIJA (Tarakanovas, Raudonius, 2003). Correlation coefficients and relationships between the indicators tested were determined using the software STATISTICA 7 (Hill, Levicki, 2005). The symbols ** and * used in this work represent statistically significant at $99 \%$ and $95 \%$ probability level; $\mathrm{LSD}_{05}$ the least significant difference at $95 \%$ probability level.

\section{Results and discussion}

According to the data of three-year tests, the effect of the amino acids on the yield of the winter wheat 'Širvinta 1' differed between years (Table 1).

Table 1. The effect of different concentrations of amino acids in the fertilizer, applied at the winter wheat heading stage (BBCH 51-56), on the grain yield

\begin{tabular}{ccccc}
\hline \multirow{2}{*}{ Treatment } & \multicolumn{4}{c}{ Grain yield $\mathrm{Mg} \mathrm{ha}^{-1}$} \\
\cline { 2 - 5 } & 2007 & 2008 & 2009 & average \\
\hline $\begin{array}{c}\mathrm{N}_{150} \mathrm{P}_{90} \mathrm{~K}_{90} \\
\text { (background) }\end{array}$ & $4.88 \mathrm{c}$ & $6.57 \mathrm{~d}$ & $6.94 \mathrm{~d}$ & $6.13 \mathrm{~d}$ \\
$0.5 \%$ amino acids & $5.08 \mathrm{~b}$ & $6.67 \mathrm{~cd}$ & $7.34 \mathrm{a}$ & $6.36 \mathrm{~b}$ \\
$1.0 \%$ amino acids & $5.26 \mathrm{a}$ & $6.97 \mathrm{ab}$ & $7.27 \mathrm{~b}$ & $6.50 \mathrm{a}$ \\
$1.5 \%$ amino acids & $4.87 \mathrm{c}$ & $7.12 \mathrm{a}$ & $7.24 \mathrm{~b}$ & $6.41 \mathrm{ab}$ \\
$2.0 \%$ amino acids & $5.19 \mathrm{a}$ & $6.80 \mathrm{bc}$ & $7.23 \mathrm{bc}$ & $6.41 \mathrm{ab}$ \\
$2.5 \%$ amino acids & $4.88 \mathrm{c}$ & $6.74 \mathrm{~cd}$ & $7.17 \mathrm{c}$ & $6.26 \mathrm{c}$ \\
$3.0 \%$ amino acids & $5.05 \mathrm{~b}$ & $6.70 \mathrm{~cd}$ & $6.81 \mathrm{e}$ & $6.19 \mathrm{~cd}$ \\
\hline $\mathrm{LSD}_{05}$ & 0.102 & 0.179 & 0.074 & 0.130 \\
\hline
\end{tabular}

Note. Means not sharing a common letter $(\mathrm{a}, \mathrm{b}, \mathrm{c}, \mathrm{d})$ are significantly different $(P<0.05)$.

In 2007, the highest grain yield of the winter wheat was from the treatments fertilized with the liquid amide nitrogen fertilizers with $1.0 \%$ concentration of amino acids, the yield increase was $7.8 \%$ compared with the control. In addition, an essential yield increase (0.17$0.31 \mathrm{Mg} \mathrm{ha}^{-1}$ ) was obtained in the treatments applied with the liquid amide nitrogen fertilizers with $0.5,2.0$ and $3.0 \%$ concentrations of amino acids.

In 2008, the winter wheat yield changed consistently under the effect of the amino acids. With increasing the concentration of amino acids to $1.5 \%$, the grain yield increased, and from $2.0 \%$ it decreased. That year, depending on the concentration of amino acids in the fertilizer, the yield of the winter wheat increased from $1.5 \%$ to $8.4 \%$.

The most abundant yield of the winter wheat was in 2009. During the heading stage, when using the liquid amide nitrogen containing $0.5-2.5 \%$ concentrations of amino acids there was obtained an essential yield increase of $0.23-0.40 \mathrm{Mg} \mathrm{ha}^{-1}$. 
The evaluation of the three-year data showed that the fertilizers with the amino acids used for the winter wheat during the heading stage increased the grain productivity by $0.10-6.04 \%$. During this stage, the essential increase of winter wheat yield $(0.13-$ $\left.0.37 \mathrm{Mg} \mathrm{ha}^{-1}\right)$ resulted from the solutions of $0.5-2.5 \%$ concentrations of amino acids. The most abundant grain yield $6.50 \mathrm{Mg} \mathrm{ha}^{-1}$ was achieved when fertilizing with $1.0 \%$ concentration of amino acids. Very intense cell division and metabolism of protein and biologically active substances in Poaceae plants occur during the heading stage under a good moisture regime and mineral nutrition, cereals ear and bloom later; however, there are more flowers and they are lager (Masilionyte, Maikštėnienè, 2011). Therefore, it is likely that during this stage, the liquid amide nitrogen fertilizers with the amino acids tended to activate physiological processes which occurred in the cells of the winter wheat and, also, increased the grain productivity.

The correlation regression analysis showed that the grain productivity of the winter wheat was correlated with the amount of amino acids in the fertilizer $(\eta=$ $\left.0.93^{*}\right)$ and changed following a quadratic equation: $y=$ $6.1731+0.3847 \mathrm{x}-0.1312 \mathrm{x}^{2}$ (Fig. 1).

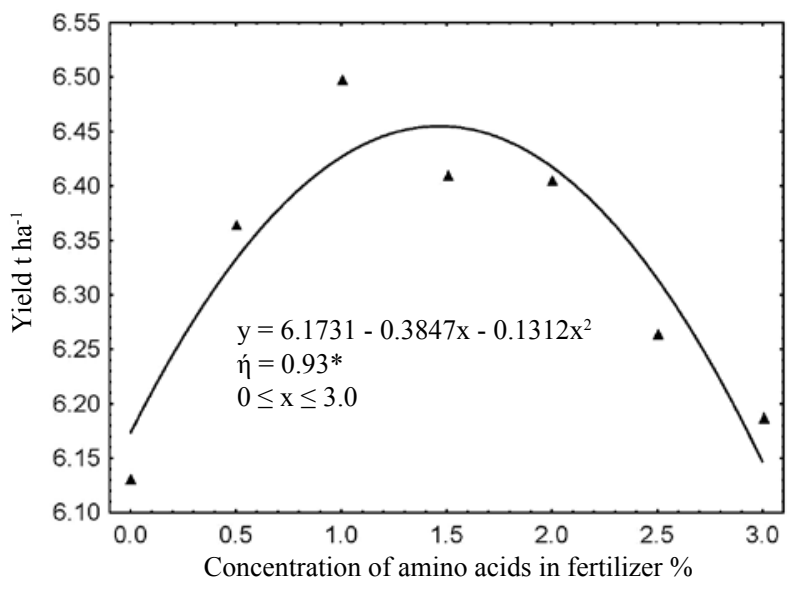

Figure 1. The dependence of winter wheat grain yield $\left(\mathrm{y}, \mathrm{Mg} \mathrm{ha}^{-1}\right)$ on the amino acid concentration $(\mathrm{x}, \%)$ in the fertilizers
According to the calculations, the maximum yield could be achieved when fertilizing the winter wheat at the heading stage with $1.47 \%$ amino acid solution.

The protein content in winter wheat grain depended on the meteorological conditions of the year (Fig. 2). Scientific literature indicates that not only the mineral nitrogen nutrition, but, also, weather conditions, moisture and heat regime, during grain filling and maturation stages, have a high significance on the grain protein content (Johansson et al., 2003; Janušauskaite, Šidlauskas, 2004; Krištaponytė, Maikštėnienè, 2004). This could lead to differences in the process of protein accumulation in the winter wheat grains in different research years.

In 2007, the amount of protein increased in the grains. The essential increase of this indicator was determined in the grain of winter wheat fertilized with $1.5 \%$ and $2.0 \%$ concentrations of amino acids, during the heading stage (Fig. 2).

According to the data of 2008 research, the liquid amide nitrogen fertilizer with $0.5,1.0,1.5,2.0$ and $3.0 \%$ concentrations of amino acids essentially (0.71$1.59 \%$ ) increased the protein content in the grains.

In 2009, the winter wheat matured grains with essentially higher protein content (from $2.45 \%$ till $5.13 \%)$ in all the treatments applied with the fertilizers containing amino acids at the heading stage.

Averaged three-year data showed that the amino acid fertilizers increased the protein content in winter wheat grain. When applying the winter crops with the fertilizers with $0.5-2.0 \%$ concentrations of the amino acids, during the heading stage, the protein content in the grains significantly increased (by $0.62-0.81$ percentage points). The grains with the highest protein content $(13.96 \%)$ were matured by the winter wheat, applied with the liquid amide nitrogen fertilizers with $0.5 \%$ concentration of amino acids.

The correlation regression analysis revealed a significant, moderate correlation $\left(\eta=0.70^{*}\right)$ between the protein content of the winter wheat grains and the amino acid concentrations in the fertilizer. The relationship is described by the quadratic regression equation: $\mathrm{y}=$ $13.3475+0.7634 x-0.2484 x^{2}$ (Fig. 3.)

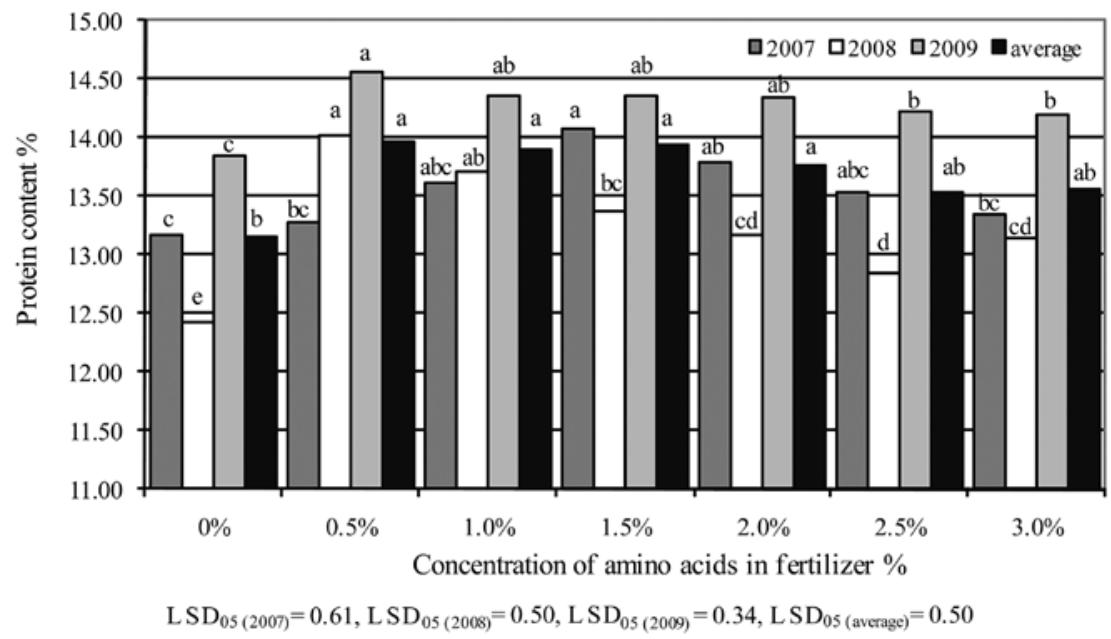

Note. Means not sharing a common letter $(\mathrm{a}, \mathrm{b}, \mathrm{c}, \mathrm{d}, \mathrm{e})$ are significantly different $(P<0.05)$.

Figure 2. The effect of different concentrations of amino acids in the fertilizer, applied at the winter wheat heading stage (BBCH 51-56), on the grain protein content 


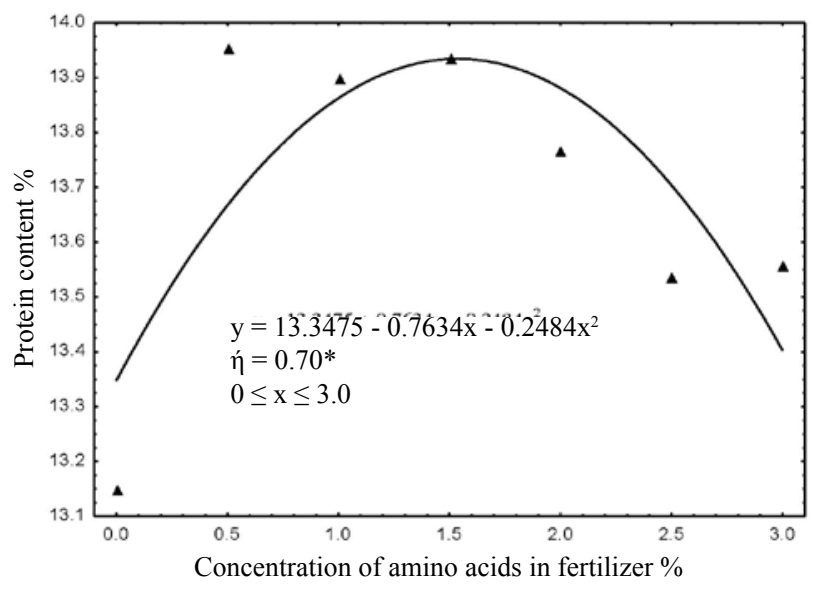

Figure 3. The relationship between protein content in winter wheat grain $(y, \%)$ and the amino acid concentration $(\mathrm{x}, \%)$ in the fertilizer

The amino acid fertilizers, used at the heading stage, increased not only the protein content in the grains, but, also, other grain quality indicators. In the different research years, tendencies of sedimentation value changes were different. In 2007, the sedimentation values of grown wheat grains matched the quality class ( $>35$ ) conditions (Fig. 4). When applying the fertilizers with $0.5-3.0 \%$ concentrations of amino acids, during the heading stage, the sedimentation values were increased. However, the essential increase $(4 \mathrm{ml})$ was when the winter wheat was fertilized with $2.0-3.0 \%$ concentrations of amino acid fertilizers.

In 2008, the solutions of all the concentrations of amino acids essentially increased the sedimentation values $(2-4 \mathrm{ml})$. It should be noted that in 2008 the values of grain sedimentation were $41 \%$ and $47 \%$ lower compared with the data of 2007 and 2009. This could have resulted from extremely dry month of June. Research sources claim that when a drought occurs after flowering, it accelerates formation of solids, but shortens the grain filling period, and this has a negative impact on the sedimentation values and on the insoluble polymeric protein content in the grains (Samarah, 2005).

In 2009, the essential increase of sedimentation values was 3-5 $\mathrm{ml}$, because of the effect of amino acids. The averaged three-year data showed that all the

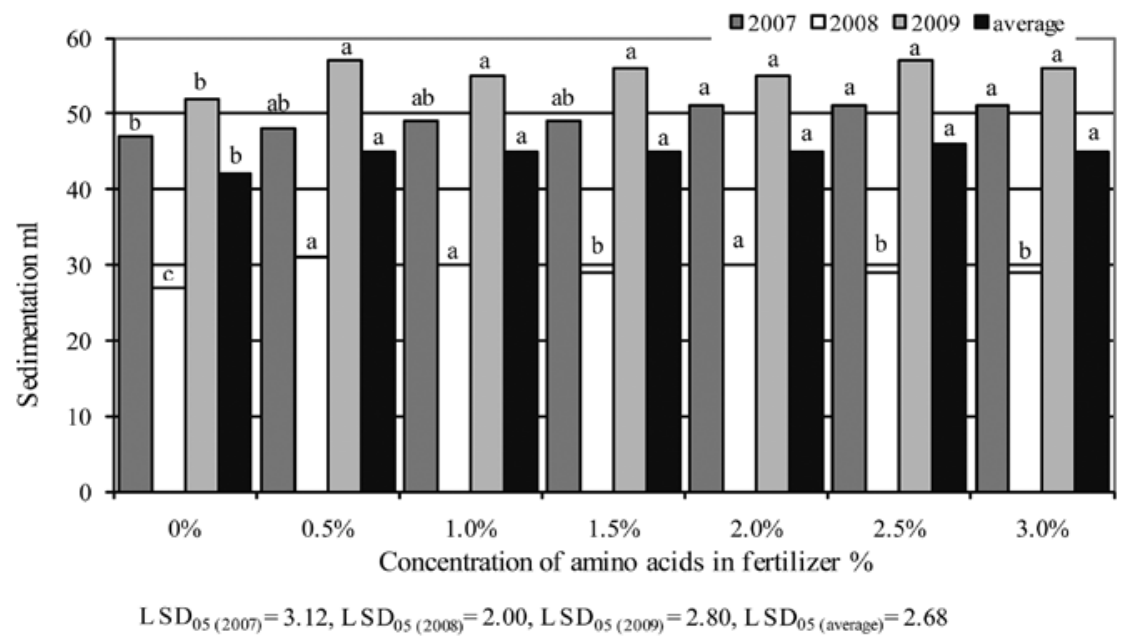

Note. Means not sharing a common letter $(\mathrm{a}, \mathrm{b}, \mathrm{c})$ are significantly different $(P<0.05)$.

Figure 4. The effect of different concentrations of amino acids in the fertilizer, applied at the winter wheat heading stage (BBCH 51-56), on the sedimentation volume

concentrations $(0.5-3.0 \%)$ of amino acids used in the research essentially increased the sedimentation values in the grains of winter wheat. The relationship between this indicator and the concentrations of amino acids in the fertilizer is best shown by the quadratic correlation (Fig. 5). The correlation was very strong $\left(\left(\eta=0.98^{*}\right)\right.$.

A multiple correlation regression analysis confirmed that the sedimentation values of grains depended on the amount of amino acids in the fertilizer and on the protein content in the grains. The relationship is described by the quadratic equation: $\mathrm{y}=3.668175+$ $0.100000 x_{1}+25.15766 x_{2}-9.90776 x_{3}$.

Another important indicator of the grain quality is the wet gluten content, which must not be below $28 \%$ for food grains of the first class. In 2007, the indicator complied with the requirements of this class (Table 2). When the plants were applied with the fertilizers containing amino acids, the content of wet gluten in the grains slightly increased. In addition, the essential effect

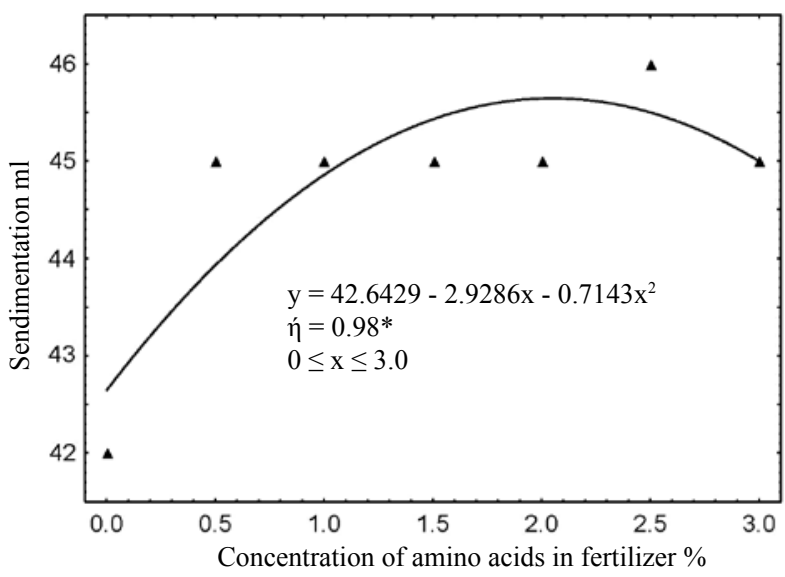

Figure 5. The relationship between winter wheat grain sedimentation $(\mathrm{y}, \%)$ and the amino acid concentration $(\mathrm{x}, \%)$ in the fertilizer 
of the fertilizers was determined when applying 1.0, 2.0 and $2.5 \%$ concentrations of amino acids.

Table 2. The effect of different concentrations of amino acids in the fertilizer, applied at the winter wheat heading stage (BBCH 51-56), on the wet gluten

\begin{tabular}{ccccc}
\hline \multirow{2}{*}{ Treatment } & \multicolumn{4}{c}{ Wet gluten \% } \\
\cline { 2 - 5 } & 2007 & 2008 & 2009 & average \\
\hline $\begin{array}{c}\mathrm{N}_{150} \mathrm{P}_{90} \mathrm{~K}_{90} \\
\text { (background) }\end{array}$ & $30.9 \mathrm{~d}$ & $26.4 \mathrm{~b}$ & $31.5 \mathrm{~b}$ & $29.6 \mathrm{~b}$ \\
$0.5 \%$ amino acids & $31.1 \mathrm{~b} \mathrm{~cd}$ & $29.7 \mathrm{a}$ & $33.1 \mathrm{a}$ & $31.3 \mathrm{a}$ \\
$1.0 \%$ amino acids & $32.1 \mathrm{ab}$ & $29.2 \mathrm{a}$ & $32.5 \mathrm{ab}$ & $31.3 \mathrm{a}$ \\
$1.5 \%$ amino acids & $30.4 \mathrm{~d}$ & $28.9 \mathrm{a}$ & $32.9 \mathrm{a}$ & $30.7 \mathrm{ab}$ \\
$2.0 \%$ amino acids & $32.0 \mathrm{abc}$ & $27.1 \mathrm{~b}$ & $32.9 \mathrm{a}$ & $30.7 \mathrm{ab}$ \\
$2.5 \%$ amino acids & $32.7 \mathrm{a}$ & $26.6 \mathrm{~b}$ & $32.2 \mathrm{ab}$ & $30.5 \mathrm{ab}$ \\
$3.0 \%$ amino acids & $31.0 \mathrm{c}$ & $27.0 \mathrm{~b}$ & $32.4 \mathrm{ab}$ & $30.1 \mathrm{~b}$ \\
\hline LSD $_{05}$ & 1.09 & 1.30 & 1.11 & 1.17 \\
\hline
\end{tabular}

Note. Means not sharing a common letter $(\mathrm{a}, \mathrm{b}, \mathrm{c}, \mathrm{d})$ are significantly different $(P<0.05)$.

In 2008 , the content of wet gluten was $13 \%$ and $17 \%$ lower compared with the data of 2007 and 2009. In recent years, the meteorological conditions were particularly favourable for the high yield of winter wheat. However, qualitative indicators (protein and gluten) of the grains were worse. Because of the amino acids' effect, the wet gluten content increased by $0.2-3.3$ percentage points that year. When applying the liquid amide nitrogen fertilizers with 0.5 , 1.0 and $1.5 \%$ concentrations of amino acids on the plants, it essentially increased the content of wet gluten.

In 2009, all the solutions of amino acids increased the values of wet gluten. In addition, when the winter crops were fertilized with the fertilizers with 0.5 , 1.5 and $2.0 \%$ concentrations of amino acids, there was determined an increase in wet gluten in the grains.

According to averaged data of 2007-2009, it could be claimed that the amino acids increased the content of wet gluten in the grains of winter wheat. The best results were obtained when the solutions of $0.5-2.0 \%$ amino acids concentrations were used. With increasing concentration of amino acids, the content of wet gluten decreased.

The scientific literature indicates that the gluten content depends on grain protein composition and statistically significantly correlates with the protein content in grain (Šip et al., 2000; Johansson et al., 2003; Tranavičienè, 2009). This study confirmed this statement, it was described by a linear regression equation $\mathrm{y}=$ $4.4085+1.9134 x$ (Fig. 6).

The falling number of winter wheat grain in all experimental years met the quality requirements (LST 1524:2003) of the first class food wheat (>220 s) (Table 3).

In 2007 , the falling number of grain increased by an average of $10.2 \%$ and in 2008 by an average of $9.8 \%$, this resulted from the effect of amino acids. In 2009 , there were determined significant differences in the highest grain falling number, compared with all the three-year data. The averaged three-year data showed, that when applying the liquid amide nitrogen fertilizers with $1.0 \%$ concentration of amino acids on the winter wheat at heading stage, the values of grain falling number increased by $22 \mathrm{~s}$. However, the other tested concentrations of amino acid solutions had no significant influence on the values of grain falling number.

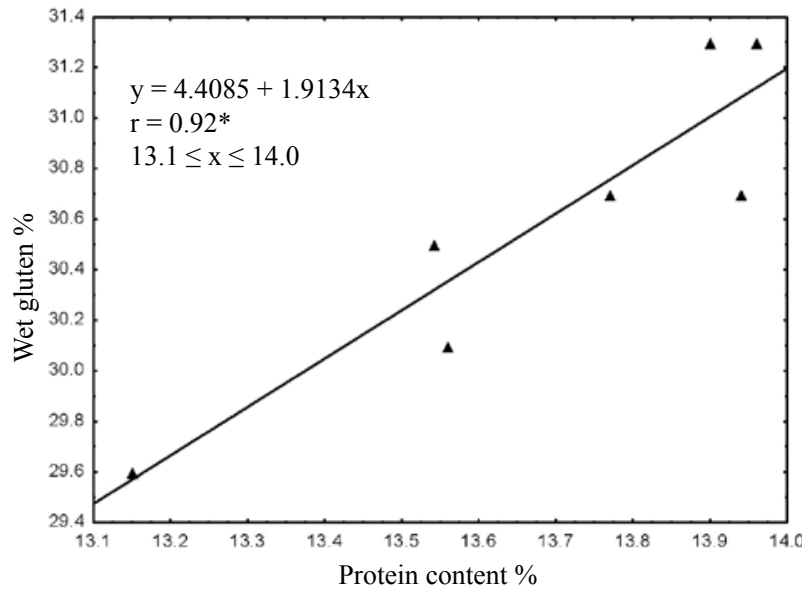

Figure 6. The relationship between wet gluten (y, \%) and protein content $(\mathrm{x}, \%)$ in winter wheat grain

Table 3. The effect of different concentrations of amino acids in the fertilizer, applied at the winter wheat heading stage (BBCH 51-56), on the falling number

\begin{tabular}{ccccc}
\hline \multirow{2}{*}{ Treatment } & \multicolumn{4}{c}{ Falling numbers } \\
\cline { 2 - 5 } & 2007 & 2008 & 2009 & average \\
\hline $\mathrm{N}_{150} \mathrm{P}_{90} \mathrm{~K}_{90}$ & $254 \mathrm{c}$ & $244 \mathrm{~b}$ & $320 \mathrm{ab}$ & $273 \mathrm{bc}$ \\
(background) & & & & \\
$0.5 \%$ amino acids & $296 \mathrm{a}$ & $280 \mathrm{a}$ & $300 \mathrm{bcd}$ & $292 \mathrm{ab}$ \\
$1.0 \%$ amino acids & $280 \mathrm{ab}$ & $272 \mathrm{a}$ & $332 \mathrm{a}$ & $295 \mathrm{a}$ \\
$1.5 \%$ amino acids & $262 \mathrm{bc}$ & $276 \mathrm{a}$ & $287 \mathrm{~d}$ & $275 \mathrm{abc}$ \\
$2.0 \%$ amino acids & $257 \mathrm{c}$ & $237 \mathrm{~b}$ & $295 \mathrm{~cd}$ & $263 \mathrm{c}$ \\
$2.5 \%$ amino acids & $292 \mathrm{a}$ & $271 \mathrm{a}$ & $312 \mathrm{abc}$ & $292 \mathrm{ab}$ \\
$3.0 \%$ amino acids & $292 \mathrm{a}$ & $271 \mathrm{a}$ & $290 \mathrm{~cd}$ & $284 \mathrm{abc}$ \\
\hline LSD $_{05}$ & 20.42 & 21.05 & 23.01 & 21.52 \\
\hline
\end{tabular}

Note. Means not sharing a common letter $(\mathrm{a}, \mathrm{b}, \mathrm{c}, \mathrm{d})$ are significantly different $(P<0.05)$.

\section{Conclusions}

1. The liquid amide nitrogen fertilizers with $0.5-3.0 \%$ concentrations of amino acids, applied on the winter wheat at heading stage, increased grain productivity by $0.13-0.37 \mathrm{Mg} \mathrm{ha}^{-1}$. The maximum grain yield could be achieved when fertilizing during this stage with fertilizers with $1.47 \%$ of amino acids.

2. Having fertilized with $0.5-2.0 \%$ amino acid solutions, the protein content increased by 0.62-0.81 percentage points; having fertilized with $0.5-$ $3.0 \%$ solutions, the sedimentation values increased by $3-4 \mathrm{ml}$; and having fertilized with $0.5-1.0 \%$ amino acid solutions, the wet gluten content increased by 1.1-1.7 percentage units. An increase in the falling number by $22 \mathrm{~s}$ occurred having fertilized with $1.0 \%$ amino acid solution.

3. A close correlation was determined between the concentration of amino acids in the fertilizer and the productivity of winter wheat grains $\left(\eta=0.93^{*}\right)$, the protein content $\left(\eta=0.70^{*}\right)$, the indicators of sedimentation $(\eta=$ $0.98 *)$. 


\section{References}

Alaru M., Laur U., Jaama E. 2003. Influence of nitrogen and weather conditions on the grain quality of winter triticale. Agronomy Research, 1:3-10

Azevedo R. A., Lancien M., Lea P. J. 2006. The aspartic acid metabolic pathway, an exciting and essential pathway in nlants. Amino Acids. 30: 143-162 http://dx.doi.org/10.1007/s00726-005-0245-2

Daniel C., Triboi E. 2000. Effects of temperature and nitrogen nutrition on the grain composition of winter wheat: effects on gliadin content and composition. Journal of Cereal Science. 32: 45-56 http://dx.doi.org/10.1006/jcrs.2000.0313

Dreccer M. F., Oijen M., Schapendonk A. 2000. Dynamics of vertical leaf nitrogen distribution in a vegetative wheat canopy. Impact on canopy photosynthesis. Annals of Botanv. 86: 821-831 http://dx.doi.org/10.1006/anbo.2000.1244

Hill T., Levicki P. 2005. Statistics methods and applications. Madison, USA, $800 \mathrm{p}$.

Janušauskaitè D., Šidlauskas G. 2004. Nitrogen fertilizer efficacy in winter wheat in relation to weather conditions in Central Lithuania. Zemdirbyste-Agriculture, 88 (4): 34-47 (in Lithuanian)

Johansson E., Prieto-Linde M. L., Svensson G., Jonsson J. O. 2003. Influences of cultivar, cultivation year and fertilizer rate on amount of protein groups and amount and size distribution of mono- and polymeric proteins. Journal of Agricultural Science. 140: 275-284 http://dx.doi.org/10.1017/S0021859603003162

Krištaponytė I., Maikštėnienè S. 2004. The influence of nitrogen fertiliser rates on winter wheat (Triticum aestivum L.) grain yield and quality. Žemès ūkio mokslai, 4: 7-14 (in Lithuanian)

Masilionytė L., Maikštenienė S. 2011. The effect of agronomic and climatic factors on the accumulation of nutrients in the yield of main and catch crops. Zemdirbyste-Agriculture, 98 (3): 235-244

Meijer A. J. 2003. Amino acids as regulators and components of nonproteinogenic pathways. The Journal of Nutrition, 39: 2057-2062

Nikiforova V. J, Bielecka M., Gakiere B., Krueger S., Rinder J., Kempa S., Morcuende R., Scheible W. R., Hesse H.,
Hoefgen R. 2006. Effect of sulfur availability on the integrity of amino acid biosynthesis in plants. Amino Acids, 30: 173-183

http://dx.doi.org/10.1007/s00726-005-0251-4

Samarah N. H. 2005. Effects of drought stress on growth and yield of barely. Agronomy for Sustainable Development, 25: 145-149 http://dx.doi.org/10.1051/agro:2004064

Sharma-Natu P., Ghildiyal M. 2005. Potential targets for improving photosynthesis and crop yield. Current Science, 88: $1918-1928$

Sylvester-Bradley, Davies D. B., Dyer C., Rahn C., Johnson P. A. 1997. The value of nitrogen applied to wheat during early development. Nutrient Cycling in Agroecosystems, 47 (2): 173-180 http://dx.doi.org/10.1007/BF01991549

Šip V., Skorpik M., Chrpova J., Sottnikova V., Bartova S. 2000. Effect of cultivar and cultural practices on grain yield and bread-making quality of winter wheat. Rostlinna vyroba, 46 (4): 159-167

Švec I., Hruškova M., Jirsa O. 2006. Evaluation of winter wheat varieties from three harvest years. Getreidetechnologie, 60: $78-86$

Tarakanovas P., Raudonius S. 2003. Agronominių tyrimų duomenų statistinè analizè taikant kompiuterines programas ANOVA, STAT, SPLIT-PLOT iš paketo SELEKCIJA ir IRRISTAT. Akademija, Kauno r., 58 p. (in Lithuanian)

Tranavičienè T. 2009. Azoto poveikis skirtingų paprastojo kviečio (Triticum aestivum L.) veislių fotosintezès ir grūdų kokybès rodikliams: daktaro disertacija. Akademija, Kauno r., 89 p. (in Lithuanian)

Vernieri P., Borghesi E., Ferrante A., Magnani G. 2005. Application of biostimulants in floating system for improving rocket quality. Journal of Food, Agriculture and Environment, 3: 86-88

Woolfolk C. W., Raun W. R., Johnson G. V. 2002. Influence of late-season foliar nitrogen application on yield and grain in winter wheat. Agronomy Journal, 94: 429-434 http://dx.doi.org/10.2134/agronj2002.0429

Лёвкин В. Н. 2007. Удобрения и качество зерна мягкой озимой пщеницы на светло-каштанавых почвах нижнегоповолжья. Аграрный вестник Урала, 5 (41): 31-33 (in Russian)

ISSN 1392-3196

Zemdirbyste-Agriculture, vol. 100, No. 1 (2013), p. 57-62

UDK 633.11:631.8:631.55 / DOI 10.13080/z-a.2013.100.008

\title{
Paprastụjų žieminių kviečių technologinių savybių kitimas tręšiant aminorūgščių trąšomis
}

\author{
R. Dromantienė, I. Pranckietienè, G. Šidlauskas, V. Pranckietis
}

Aleksandro Stulginskio universitetas

\section{Santrauka}

Veislès 'Širvinta 1' žieminiai kviečiai auginti 2006-2009 m. Lietuvos žemès ūkio universiteto (dabar - Aleksandro Stulginskio universitetas) Bandymų stotyje limnoglacialinio lengvo priemolio ant moreninio molio karbonatingame giliau glejišsame išplautžemyje (IDg4-k). Žiemkenčiai auginti patręšus $\mathrm{N}_{150} \mathrm{P}_{90} \mathrm{~K}_{90}$ mineralinėmis trąšomis, o plaukejjimo tarpsniu (BBCH 51-56) papildomai patręšti per lapus įvairių koncentracijų $(0,5-3,0 \%)$ aminorūgščiu tirpalais. Tyrimų metu nustatyta, kad aminorūgščių trąšos žieminių kviečių derlingumą padidino $0,13-0,37 \mathrm{Mg}$ $\mathrm{ha}^{-1}$. Šios trąšos pagerino ir grūdų technologines savybes. Patręšus $0,5-2,0$ \% aminorūgčių tirpalais baltymų kiekis padidejo 0,62-0,81 proc. vnt., patręšus $0,5-3,0 \%$ tirpalais sedimentacijos vertės padidejo $3-4 \mathrm{ml}, 0,5-1,0 \%$ aminorūgščiu tirpalai šlapiojo glitimo kieki padidino $1,1-1,7$ proc. vnt., o kritimo skaičius padidejo $22 \mathrm{~s}$ patręšus $1,0 \%$ aminorūgščių tirpalu. Tyrimų metu nustatytas esminis žieminių kviečių grūdų derlingumo $(\eta=0,93 *)$ baltymingumo $\left(\eta=0,70^{*}\right)$ ir sedimentacijos verčių $\left(\eta=0,98^{*}\right)$ priklausomumas nuo aminorūgščių koncentracijos skystosiose amidinio azoto trąšose.

Reikšminiai žodžiai: aminorūgštys, baltymingumas, grūdų derlius, kritimo skaičius, plaukejjimo tarpsnis, sedimentacija, šlapiasis glitimas, Triticum aestivum. 